依 頼 論 文

特集 : 日本補綴歯科学会第 121 回学術大会 シンポジウム 2

「咬合咀嚼は健康長寿にどのように貢献しているのか」

\author{
咬合・咀嚼は健康長寿にどのように貢献しているのか \\ 一文献レビューを中心に一 \\ 池邊 一典
}

\title{
How Do Occlusion and Masticatory Function Contribute to General Health and Longevity? -A Review of Literature-
}

Kazunori Ikebe, DDS, PhD

\begin{abstract}
抄 録
文献レビューによって，「咬合・咀嚼は健康長寿に貢献しているのか」を検討した。本論文では，ヒト を対象としたコホート研究を選択した。疾患の発症率や死亡率を高める因子は，喫煙や食習慣，生活習慣 病，社会経済的要因など，すでに確立されたものがいくつもある。そこでそれらの交絡因子の影響を，多 変量解析を用いて統計学的に調整した研究を採用した。

その結果，以下のことが明らかとなった．1）歯数は長寿と関連している．2）その経路として，歯周 病とともに口腔機能低下による栄養摂取の変化が考えられる．3）歯を失うと摂取不足になるのは，主に 野菜である。また野菜不足は心血管系疾患と関連がある。4) 無歯顎や多数歯欠損では，義歯を使用しな いと余命が短くなる可能性がある。5）義歯の質や口腔機能と健康長寿との関係は，現在のところエビデ ンスがほとんどない.
\end{abstract}

和文キーワード

縱断研究, 長寿, 心血管系疾患, 歯数, 咀嚼, 栄養, 義歯, 交絡因子

\section{I 、はじめに}

私の基本的な立場として，歯科治療本来の目的である 口腔機能の回復は，それだけで十分価值があると思って いる，食べること，味わうこと，人と会話を交わすこと は，言うまでもなく根源的な楽しみである．特に高齢者 では, いかに美味しく何でも食べられるかが重要であ り, 歯科治療は, その食べることを回復する医療として 重要な役割を担っている. ストレスなく, 楽しく, 家族 や友人と同じものを食べられるということは，精神的な 充実や QOL の向上にもつながる.

しかし最近の傾向として, 口腔の健康あるいは歯科治 療が，全身状態に影響を及ぼすということを強調しす ぎ，そのイメージが独り歩きしている印象を受ける。確
かに，歯科治療が全身状態の改善に寄与するという事実 は, 歯科医師にとって, とても魅力的である.しかし, たとえば歯周病あるいはその治療は, 循環器系疾患や糖 尿病との関係がなければ価值がないとは思わない，最近 は，マスコミの影響か，そのような全身疾患を主訴とし て歯科を来院する患者も増えているが，われわれは，全 身状態を改善することを第一の目標に歯科治療を行って いるのではない，全身状態の改善があるとすれば，それ は歯科治療による口腔機能の回復の結果として後からつ いてくるものと考えている.

その一方で, 口腔と全身との真の関係を，科学的根拠 に基づいて，公平に，真摰に検討することは，われわれ 歯科医師に求められる重要な責務であると考える。 その ことによって，玉石混交の諸説の中から，自信を持って 言える真実のみを広く一般の人々に伝えるべきである. 
今回の文献レビューは, 咬合・咀嚼は「なぜ」健康長 寿に貢献しているのかを考察するにあたっての私の思考 過程であり，それを裏付ける論文の紹介であるが，シス テマティックレビューではないことを最初にお断りして おく.

\section{II．本論で取り上げた論文}

今回は，エビデンスレベルの高い，ヒトを対象とした コホート研究を取り上げた。「咬合・咀嚼は健康長寿に 貢献しているのか」を明らかにするためには，厳密に言 うと,「咬合・咀嚼の改善」が,「健康を回復する」, あ るいは「寿命を伸ばす」という仮説を長期的な縦断的研 究で検証しなければならない.

しかし，ヒトを対象とした研究において，たとえば実 験的に咬合・咀嚼を改善する群としない群をランダムに 割り付けし，それらが，死亡あるいは疾患に罹患するま で追跡するといった介入研究は, 倫理的側面から現実的 には不可能である。そこでこれまでは, ベースラインの 調査時に, 健康な被験者を歯の状態がよい群と悪い群に 分け，一定期間ののち，両者の死亡率や疾患の発症率を 比較する観察研究が多い (図 1)。このような研究では, 歯の状態と死亡率や疾患の発症率との 2 者の間には, ほとんどの場合有意な関連がみられる。

しかし当然ながら, 疾患の発症率や死亡率を高める要 因は, 喫煙や食習慣, 生活習慣病, 社会経済的要因など, すでに確立されたものがいくつもあり，それらの要因が 歯の状態と健康・死亡率の両者に影響を及ぼす交絡因子 となっている（図 2)。このようなことを避けるため, 喫煙のような「交絡因子」の影響を, 多変量解析を用い て統計学的に調整した研究が多い. 交絡因子を統計学的 に調整した場合, 歯の状態と健康・死亡率との関連が弱 くなり，有意でなくなることもよくある.

\section{III. 歯数と死亡率, 長寿}

歯数と死亡率との関係を取り上げた研究は比較的多く ある。ここでは，これまでいくつかのレヴューで高い評 価を得ている, 対象者数の多い論文を紹介する. NIH の Abnet らは, 中国で 40 代から 60 代の約 3 万人を 10〜15 年追跡し，対象者を各年代で，たとえば 40 歳 なら 40 歳, 65 歳なら 65 歳で, 歯の多い群と少ない 群の 2 群に分け，その両者の死亡率を比較した ${ }^{1)}$. そ の結果，歯の少ない人のほうが，全体で $13 \% ， 心$ 疾患 に限ると $28 \%$ 死亡率が高かった。 Tuらは, イギリス で行われた研究で, 大学生約 12,600 人の 57 年後の死

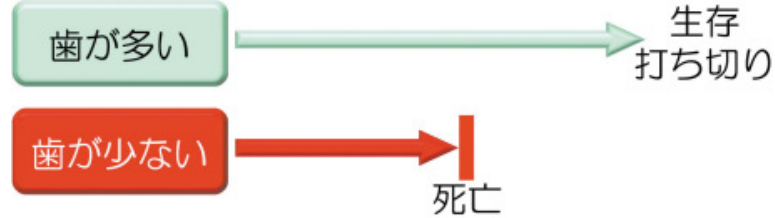

例：被験者を歯が多い群と少ない群に分け, 一定期間ののち, 両群の死亡率や疾患の発症 率を比較する観察研究.

図 1 ヒトを対象としたコホート研究

例：喫煙が心疾患に直接的な強い関係があるが，喫 煙は歯の訔失の原因ともなるため, あたかも歯の欠 損と心疾患に関連があるように見えてしまう.

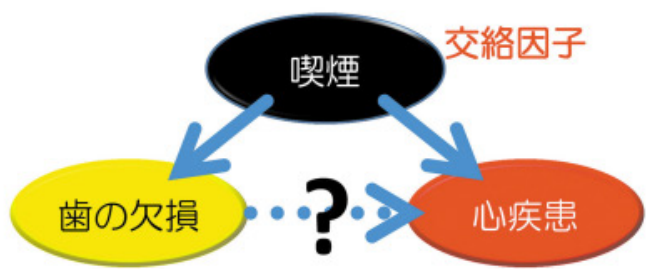

図 2 交絡因子を調整した多変量解析

亡率を調査した ${ }^{2)}$. その結果，学生当時，欠損歯数が 4 本以下の者に比べて，9本以上の者は，死亡率が高い [hazard ratio (HR) : 1.35] ことを示した. アメリカ CDC (Centers for Disease Control) の Brown は, 約 41,000 人を, 16 年間追跡した結果, 当初無歯顎で あった者の死亡率は他の 1.5 倍であったとしている ${ }^{3)}$. 本邦では, Ansai らは, 福岡県の 80 歳の地域住民約 697 人を 5.5 年追跡し, 歯数は死亡と有意に関連して いたと報告している ${ }^{4)}$.このように，考え得るさまざま な交絡因子を調整したうえでも，歯数は生命予後と関連 するという研究は他にも比較的多い ${ }^{5-10)}$.

\section{IV．歯周病と循環器系疾患}

歯の疾患が直接的原因となり死亡することはまず無い にもかかわらず，なぜ歯が少ないと短命なのか？その原 因として，歯が少ないと，死因につながる疾患になりや すいことが考えらえる，厚生労働省によれば，平成 22 年度の日本人の死因は，悪性新生物が $30 \%$ ，心疾患が 16\%，脳血管疾患が 11\%，肺炎が 10\% となってい る ${ }^{11)}$. 歯が寿命に関係するとすれば，まずはこれらの 疾患と関連があるということになる。現在よく言われて 


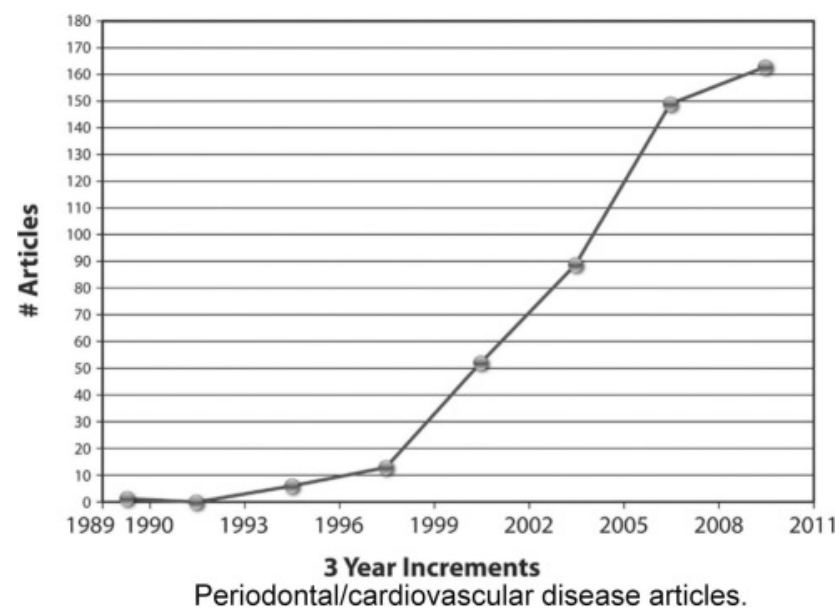

図 3 歯周病と心血管系疾患の関係を示す論文数（文献 12 より)

いるのが，心疾患，脳血管障害，肺炎と，歯周病との関 係である.

図 3 は, 循環器系で最もインパクトファクターの高 いCirculationに掲載された総説 ${ }^{12)}$ 中の, 歯周病と心 血管系疾患との関係についての論文数の 3 年ごとの推 移である. 歯周病の研究者は, 歯周病と心疾患や動脈硬 化との関係を証明するために, 戦略的に研究を進めてき た。 20 年前はほとんど報告がなかったが，2000 年以 降，関連論文数が急増し，ここ最近は 3 年間で 150 編 を超えている，その結果，これまで言われてきたリスク ファクターを調整したうえでも，因果関係は不明なもの の，「歯周病は，他の因子とは独立して，硬化性血管疾 患と有意な関連がある.」というコンセンサスが得られ るようになっている。

\section{V．咀嚼と死亡率，長寿}

では改めて，「なぜ歯が少ないと短命」なのであろう か? 歯の欠損は, 歯周病の結果であり, その歯周病は, 心血管系疾患の危険因子であるからなのか？しかし，疫 学研究からは，歯数は歯周病とは独立して死亡率と関連 する，あるいは歯周病は有意な関連がなく歯数のみ死亡 率と関連することを示す報告も多い ${ }^{8,9,13)}$.

歯周病は，感染と炎症を介して，心・脳血管系疾患に 関連していると言われている。しかしもう一つ重要な経 路が考えられる，それは，咀嚼と與下が，食事や栄養を 介して，全身の健康に及ぼす影響である（図 4)。食事 は毎日のことであるし，栄養は当然，咀嚼と嚥下を介し てしか，通常は摂取することはできない。このように， 咀嚼機能も歯周病に負けず劣らず重要と考えられるが, 科学的根拠がそしいため，言い換えれば歯周病のように

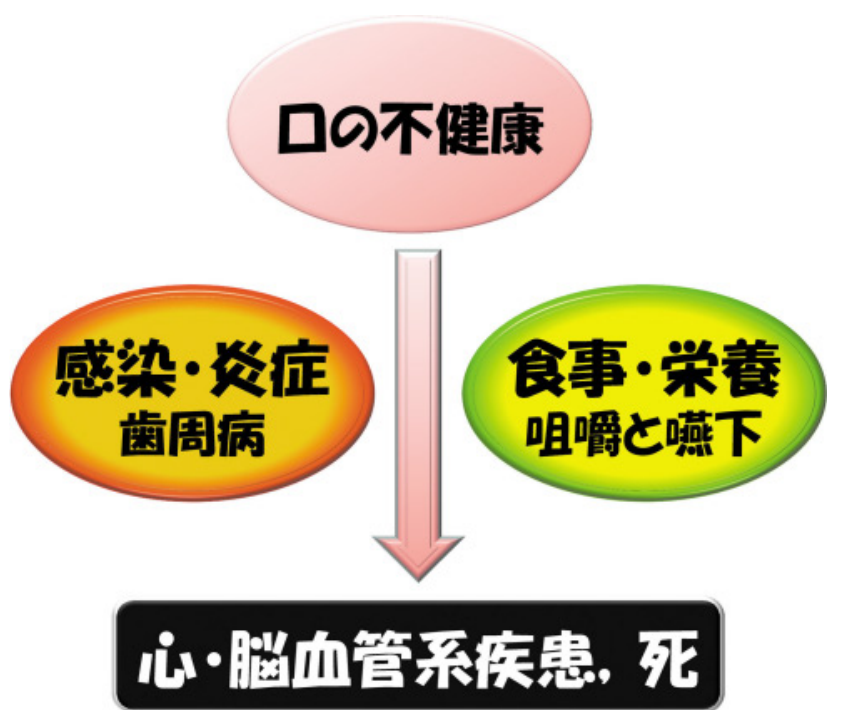

図 4 口の不健康が心・脳血管系疾患や死亡に影響を及ぼ す2つの経路

科学的根拠を確立する努力を怠ってきたため，注目され ることが少なかったと言える．Nakanishi らは，65 歳 以上の地域住民 1,405 人について, 7 年後の死亡率は, 咀嚼能力の自己評価の低い者が，他のすべての要因を調 整しても有意に高かったと報告した［調整済み hazard ratio (HR) : 1.63] ${ }^{14)}$. Ansai らは，80 歳の地域住民 の 4 年後の死亡率について, 摂取可能食品が最少の群 は，すべて食べられると回答した群より，全死亡率（調 整済夕 HR : 2.38) ${ }^{15}$ ），心血管系疾患の死亡率（調整済 み HR : 4.60) ${ }^{16)}$ とも有意に大きかったとしている. Aida らは，65 歳以上 4,425 人を 4 年間追跡調査し, 残存歯が 20 本以上の者に比べ，19 本以下で食べにく い食品のある者は，心血管系疾患（調整済み HR： 1.83), 呼吸器系疾患（調整済多 HR：1.85）による死 亡率がいずれも高かったと報告している ${ }^{17)}$.

特筆すべきは，上記の咀嚼と死亡率との関係について の研究は，いずれも日本の研究者によることである。ま た私自身が惜しいと思うのは，咀嚼の評価法は，いずれ も被験者の主観的評価であることである，われわれは， 咀嚼の主観的評価が，実際に測定した客観的評価と必ず しも一致しないことを報告している ${ }^{18)}$.

\section{VI，歯と栄養}

歯が少ないと，野菜の摂取が減るという研究結果は， 古くからある ${ }^{19-24)}$. Hung らは，アメリカの 8 万人以 上の女性を調査し，無歯顎者は，25 歯以上の者に比べ て，野菜や果物の摂取量が少なく，心血管系疾患が多い とした ${ }^{22)}$. Nowjack-Raymer らも，同じくアメリカの 
全国調査の結果, 残存歯数が 28 歯の群に対して, 歯の 欠損した人は, 野菜の摂取量が減り, その結果, 食物繊 維の摂取が少なく, 血清中の $\beta$ カロテン, ビタミン C 等が低いことを示した ${ }^{25)}$. 本邦でも，ユニークな研究 があり，Wakai らは，日本歯科医師会会員 2 万人を調 査し, 歯数の減少とともに, 野菜類, カロテン, ビタミ ン C の摂取は減少し, 逆に, 総摂取エネルギー, 炭水 化物，米，菓子類は増加したと報告している ${ }^{26)}$.

1990 年代は, 歯の状態が悪いと, 摂取エネルギーが 不足するという結果が多かったが ${ }^{27)}$, 最近では, 要介 護高齢者でない限り，歯の状態が悪いとむしろ，食事が 高カロリー高脂肪になり, 太るという結果が多くなって きている. Osterberg らは，スウェーデンで 22 年間追 跡した結果, 当初無歯顎であった人は, 肥満になる割合 が 3 倍以上になったと報告した ${ }^{28)}$ 。これも，野菜の摂 取が不足し，炭水化物や脂質の摂取が増えた結果だと推 測される。

\section{VII．野菜と全身疾患}

困ったことに，歯が悪いと食べにくいとされる野菜 が，さまざまな生活習慣病の発症にかかわっている，野 菜や果物の不足は, 心疾患や脳卒中, がんに関連する, という論文は非常に多い. 最近の大規模調査やメタアナ リシスの論文の一部を示すと, 日本人を対象に, 果物, 野菜と心血管系疾患の関係 ${ }^{29)}$, 米国の研究で, 同じよ うに心血管系疾患との関係 ${ }^{30)}$, メタアナリシスで, が んとの関係を, ${ }^{311}$, メタアナリシスで, II 型糖尿病との

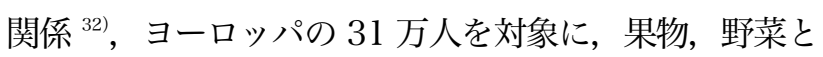
虚血性心疾患による死亡との関係 ${ }^{33}$ をそれぞれ明らか にしている.このように，野菜や果物の不足は，心疾患 や脳卒中，がんに関連するということは，すでに確立さ れたエビデンスと言える.

いままでをまとめると, 歯の減少によって, 長期間に わたり野菜や果物の摂取が不足し, その結果, 心疾患, 脳血管系疾患になりやすいというストーリーが描ける。

\section{VIII. 義歯と健康長寿}

歯数と死亡率や心血管系疾患との関係を述べてきた が，一度歯を失えば，健康が損なわれることは，防ぎよ うのないことなのであろうか? 歯を失えば，義歯を装着 することが多いが，口腔機能を回復するための義歯の役 割はどうなっているのであろうか?

最近, “歯の欠損と死亡率全体および循環器系疾患に よる死亡率との関係，補経は有効なのか?”という夕イ
トルのメタアナリシスの論文が出た ${ }^{34)}$ その論文中で は，義歯使用と死亡率との関係について，エビデンスと して採用できるのは 5 編のみで，そのうち日本の 2 編 が，中程度のエビデンスレベルの研究であったとしてい る. 残りはそれ以下のレベルである。

Fukai らは, 沖縄県宮古島の 40 歳以上, 5,700 人を, 15 年間追跡し, 女性の, しかも歯数が 10 本以下では, 義歯を装着している者に比べ，装着していない者は，生 存率が約 7 割であったと報告した ${ }^{35)}$.しかし，この関 係は，女性のみで男性ではみられず，10 本より歯数が 多いと, 義歯の装着によって死亡率に有意差はなかっ た. Yoshida らは, 広島県の 65 歳以上約 1,000 人を 8 年間追跡し，咬合支持に欠損のない Eichner A 群の 死亡率は，咬合支持の全くない $\mathrm{C}$ 群の 0.78 倍と低く, Eichner C 群の中では，義歯を装着している者に比べ装 着していない者は，死亡率が 1.5 倍と高かったとして いる ${ }^{36)}$. すなわち, 多数歯欠損の場合, 「義歯を装着し ないと長生きできない」ということになる。

Shimazaki らは, 約 2,000 人弱の介護施設入居者, 平均年齢 80 歳に対して, 6 年間の追跡を行った ${ }^{37)}$. 半 数以上が亡くなったが，2 変量間では，つまり交絡因子 の調整をしなければ，死亡率は，歯数以外に，年齢，性 別, 調査開始時の脳血管障害, 循環器系疾患, 骨関節系 疾患と有意な関連がみられた。

歯数と義歯については，20 本以上残存歯がある人を 対照群とすると, 死亡率は, 2 変量間では, 1〜19 本で 義歯を使用している人では 1.4 倍, 使用していない人 で 2.6 倍，無歯顎者では，使用している人で 1.8 倍, 使用していない人では 3.7 倍になった。 すなわち，歯 が少ないと死亡率が高まり, 義歯を使用していないと, さらに死亡率が高まるという結果である。ただし，交絡 因子を調整した多変量解析では, 対照群に対して, 無歯 顎で義歯使用なしのみ，有意に死亡率が高いという結果 になった.

Shimazaki ら ${ }^{37)}$ の結論は，“無歯顎者で，義歯を使用 しないと，歯が良い人に比べて長生きできない”である が，最良の条件と最悪の条件の間にのみ有意差があり， 部分欠損者では, 義歯装着の有無によるオッズ比は, 1.3/ 1.5, 無歯顎者でも 1.3/1.8 となり, この結果からは, 部分欠損でも無歯顎でも，義歯の使用によって死亡率に 大差はないとも言える.

一方，2012 年に入って Schwahn らは，9歯以上の 欠損を補経せずに放置すると，残存歯，年齢，性別，教 育, 収入, 夫/妻の有無, 口腔保健行動, 喫煙, 飲酒, 身体活動, 肥満, 高血圧, 糖尿病, 脂質異常症の交絡因 子を調整したうえでも，全死亡率（HR：1.43）や循環 
器系疾患による死亡率（HR：1.88）が高くなるという 報告をしている ${ }^{38)}$.

\section{IX．義歯と栄養}

健康長寿との関係で注目している栄養であるが，義歯 によって，栄養摂取が向上するというエビデンスは，今 のところ少ない.イギリスのニューカッスルの Moynihan らは，下顎両側遊離端欠損症例 60 人を，有床義歯 と延長ブリッジに無作為に割り付けて治療したところ, 3 力月後， 1 年後とも，両群間における栄養摂取に有意 差はなく，それぞれの群でも，治療前後で栄養摂取に有 意な変化はなかったとした ${ }^{399}$. Wostmann らは，施設 入所高齢者 34 人に対して，義歯再製もしくは修理前と その 6 力月後とを比較した ${ }^{40)}$ 。咀嚼能率は, 客観評価 を用いており，生ニンジンの粉砕度を 5 段階に評価し た。その結果，咀嚼能率は向上したが，栄養状態の指標 である血清アルブミンや，Mini Nutrition Assessment （栄養状態の総合評価）に変化はなかった．McGill 大 学の Awad らは，65 歳以上の上下無歯顎者に，上顎は 全部床義歯を装着し，下顎を，2 本のインプラント支台 のオーバーデンチャー (IOD, $\mathrm{n}=128)$ と従来の全部 床義歯 $(\mathrm{CD}, \mathrm{n}=127)$ に無作為に割り付けし装着し た ${ }^{41)}$. 治療 1 年後に, IOD 群は CD 群に比べて, 咀嚼 の困難な食品（牛肉，野菜，果物，ナッツ）や摂取を避 ける食品が少なくなったが，血中栄養素は両者に有意差 はみられなかった，以上の結果より，IOD は従来の CD より，咀嚼機能をより高めるという結論にしているが, 咀嚼機能の評価法が食品摂取の困難度という患者の主観 的評価であり，客観的な評価を行っていないことが惜し まれる。

\section{X. 今後の課題}

すでに行われていることもあるが，「咬合・咀嚼が創 る健康長寿」のエビデンスを確立するためには，1）妥 当性・信頼性があり，高齢者にも使用可能な，簡便・安 全な咀嚼機能評価，2）専門家による心身状態の検査・ 評価，そして 3）他の専門領域と連携した長期的縦断研 究が必要と考えられる. 特に口腔の状態として，これま では残存歯数や義歯の使用の有無を用いている研究がほ とんどであるが，「咬合・咀嚼」という機能を評価する には不十分である，言われて久しいが，補綴歯科学会と しては，質が高くかつ簡便な咬合・咀嚼の評価法の確立 が急務である.

ここでわれわれの現在の取り組みを少し紹介させてい

\section{SONIC Study}

70歳1000名 80歳1000名 90歳800名 100 歳以上 Septuagenarian Octogenarian Nonagenarian Centenarian 各コホートによる長期縱断研究 Investigation with 3年ごとに追跡調査

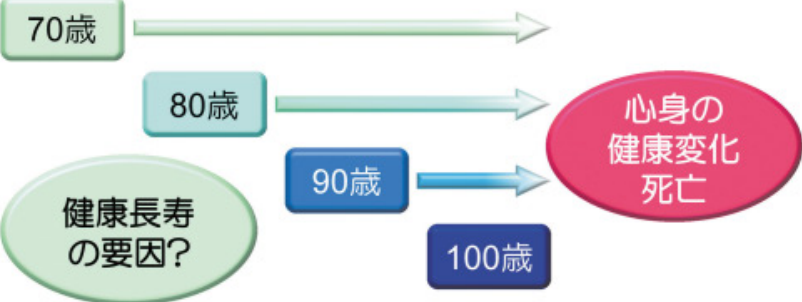

図 570 歳, 80 歳, 90 歳の各コホートの長期縦断調査 (SONIC study)

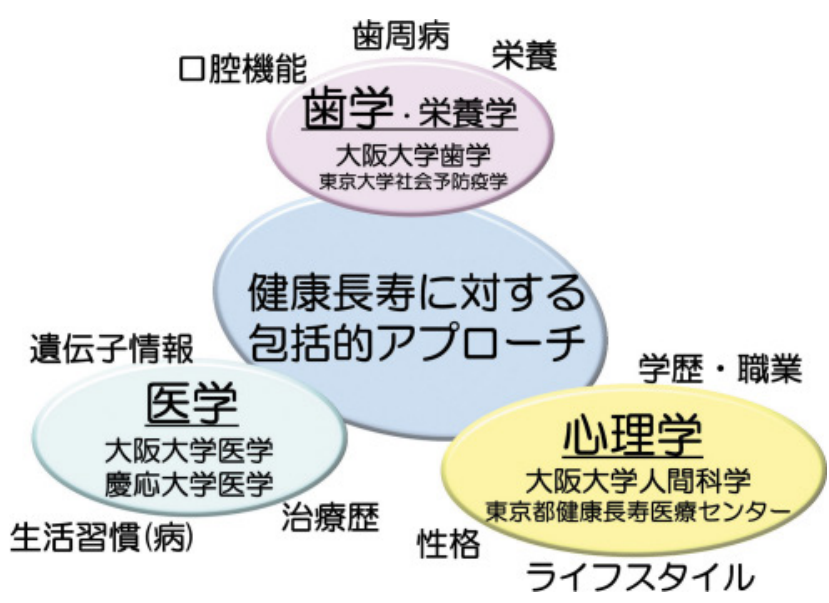

図 6 健康長寿に対する包括的アプローチ

ただく。われわれは 2010 年度より，一般住民から無 作為抽出した 70 歳 1,000 人, 80 歳 1,000 人, 90 歳 800 人の各コホートと, 100 歳以上の高齢者を対象に, 長期縦断調査によって健康長寿の要因を探索する大規模 疫学研究を進めている (図 5)。この研究は，大阪大学 人間科学研究科, 東京都健康長寿医療センター（老年心 理学), 大阪大学医学系研究科, 慶応大学医学部 (老年 内科学), 東京大学社会予防疫学 (栄養学) とわれわれ 大阪大学歯学研究科（歯科補経学，歯周病学) の共同研 究である．各コホートは，3 年ごとに追跡調査を行い， 今後生じる心身の健康状態の変化や死亡について情報を 収集する予定である。

心理学では，長寿とライフスタイルや性格，学歴や職 歴，経済状況などとの関係に興味があり，老年内科は， 遺伝子や生活習慣病，特に循環器系疾患に関心がある. わ扑れは歯や口腔機能，栄養と健康長寿との関係に関 
心が高い（図 6)。一つの専門分野で健康長寿のすべて が解決できるわけではないことは, どの研究者もがわ かっている。それぞれの専門家がデー夕を持ち寄り，そ れぞれを尊重し, 健康長寿に何が重要なのかについて, 包括的なアプローチを行っている.

\section{XI. まとめ}

今回のレヴューをまとめると以下のようになる.

1. 歯数は長寿と関連している.

2. その経路として, 歯周病とともに口腔機能低下によ る栄養摂取の変化が考えられる.

3. 歯を失うと摂取不足になるのは，主に野菜である。 また野菜不足は心疾患, 脳血管疾患を発症しやす い.

4. 無歯顎や多数歯欠損では, 義歯を使用しないと余命 が短くなる可能性がある。

5. 義歯の質や口腔機能と健康長寿との関係は, 現在の ところエビデンスがほとんどない.

\section{謝辞}

ご指導, ご協力いただいた下記の先生方に心より感謝いた します (敬称略).

香川良介, 松田謙一, 猪俣千里, 久留島悠子, 武下 肇, 岡田匡史, 宮下祐治, 村井俊介, 石田 健, 榎木香織, 多田 紗弥夏, 小川泰治, 柜山智博, 前田芳信, 野首孝祠 (以上, 大阪大学大学院歯学研究科顎口腔機能再建学講座 歯科補経 学第二教室), 権藤恭之 (大阪大学大学院人間科学研究科), 神出 計 (大阪大学大学院医学系研究科), 高橋龍太郎, 増井幸恵 (以上, 東京都健康長寿医療センター研究所), 新井康通 (慶応大学医学部), 佐々木敏, 大久保公美 (以上, 東京大学大学院医学系研究科).

\section{文献}

1) Abnet CC, Qiao YL, Dawsey SM, Dong ZW, Taylor PR, Mark SD. Tooth loss is associated with increased risk of total death and death from upper gastrointestinal cancer, heart disease, and stroke in a Chinese population-based cohort. Int J Epidemiol 2005; 34: 467-474.

2) Tu YK, Galobardes B, Smith GD, McCarron P, Jeffreys M, Gilthorpe MS. Associations between tooth loss and mortality patterns in the Glasgow Alumni Cohort. Heart 2007; 93: 1098-1 103.

3) Brown DW. Complete edentulism prior to the age of 65 years is associated with all-cause mortality. J Public Health Dent 2009; 69:260-266.
4) Ansai T, Takata Y, Soh I, Awano S, Yoshida A, Sonoki $\mathrm{K}$, et al. Relationship between tooth loss and mortality in 80-year-old Japanese community-dwelling subjects. BMCPublic Health 2010; 10:386.

5) Hamalainen P, Meurman JH, Keskinen M, Heikkinen E. Relationship between dental health and 10-year mortality in a cohort of community-dwelling elderly people. Eur J Oral Sci 2003; 11 1:291-296.

6) Cabrera C, Hakeberg M, Ahlqwist M, Wedel H, Bjorkelund C, Bengtsson C, et al. Can the relation between tooth loss and chronic disease be explained by socio-economic status? A 24-year follow-up from the population study of women in Gothenburg, Sweden. Eur JEpidemiol 2005; 20:229-236.

7) Osterberg T, Carlsson GE, Sundh V, Steen B. Number of teeth-a predictor of mortality in the elderly? A population study in three Nordic localities. Acta Odontol Scand 2007; 65:335-340.

8) Padilha DM, Hilgert JB, Hugo FN, Bos AJ, Ferrucci L. Number of teeth and mortality risk in the Baltimore Longitudinal Study of Aging. J Gerontol A Biol Sci Med Sci 2008; 63: 739-744.

9) Holmlund A, Holm G, Lind L. Number of teeth as a predictor of cardiovascular mortality in a cohort of 7,674 subjects followed for 12 years. J Periodontol 2010;81:870-876.

10) Fukai K, Takiguchi T, Ando Y, Aoyama H, Miyakawa Y, Ito G, et al. Critical tooth number without subjective dysphagia. Geriatr Gerontol Int 2011; 11: 482487.

11）厚生労働省．平成 22 年人口動態統計の年間推計. http: //www.mhlw.go.jp/toukei/saikin/hw/jinkou/suikei10/ index.html.2011 [accessed 2012.08.10].

12) Lockhart PB, Bolger AF, Papapanou PN, Osinbowale $\mathrm{O}$, Trevisan M, Levison ME, et al. Periodontal disease and atherosclerotic vascular disease: does the evidence support an independent association? a scientific statement from the American Heart Association. Circulation 2012; 125:2520-2544.

13) Volzke H, Schwahn C, Hummel A, Wolff B, Kleine V, Robinson DM, et al. Tooth loss is independently associated with the risk of acquired aortic valve sclerosis. Am Heart J 2005; 150: 1 198-1203.

14) Nakanishi N, Fukuda H, Takatorige T, Tatara K. Relationship between self-assessed masticatory disability and 9-year mortality in a cohort of communityresiding elderly people. J Am Geriatr Soc 2005; 53: 54-58.

15) Ansai T, Takata Y, Soh I, Akifusa S, Sogame A, Shimada N, et al. Relationship between chewing ability and 4-year mortality in a cohort of 80-year-old Japanese people. Oral Dis 2007; 13:214-219. 
16) Ansai T, Takata Y, Soh I, Yoshida A, Hamasaki T, Awano S, et al. Association of chewing ability with cardiovascular disease mortality in the 80-year-old Japanese population. Eur J Cardiovasc Prev Rehabil 2008; 15: 104-106.

17) Aida J, Kondo K, Yamamoto T, Hirai H, Nakade M, Osaka K, et al. Oral health and cancer, cardiovascular, and respiratory mortality of Japanese. J Dent Res 201 1;90: 1129-1135.

18) Ikebe K, Morii K, Matsuda K, Nokubi T. Discrepancy between satisfaction with mastication, food acceptability, and masticatory performance in older adults. Int J Prosthodont 2007; 20: 161-167.

19) Sheiham A, Steele J. Does the condition of the mouth and teeth affect the ability to eat certain foods, nutrient and dietary intake and nutritional status amongst older people? Public Health Nutr 200 1; 4: 797-803.

20) Ritchie CS, Joshipura K, Hung HC, Douglass CW. Nutrition as a mediator in the relation between oral and systemic disease: associations between specific measures of adult oral health and nutrition outcomes. Crit Rev Oral Biol Med 2002; 13:291-300.

21) Hung HC, Willett W, Ascherio A, Rosner BA, Rimm E, Joshipura KJ. Tooth loss and dietary intake. J Am Dent Assoc 2003; 134: 1185-1 192.

22) Hung HC, Colditz G, Joshipura KJ. The association between tooth loss and the self-reported intake of selected CVD-related nutrients and foods among US women. Community Dent Oral Epidemiol 2005; 33: 167-173.

23) Yoshihara A, Watanabe R, Nishimuta M, Hanada N, Miyazaki $\mathrm{H}$. The relationship between dietary intake and the number of teeth in elderly Japanese subjects. Gerodontology 2005; 22: 21 1-218.

24) Yoshida M, Kikutani T, Yoshikawa M, Tsuga K, Kimura M, Akagawa Y. Correlation between dental and nutritional status in community-dwelling elderly Japanese. Geriatr Gerontol Int 201 1; 1 1:315-319.

25) Nowjack-Raymer RE, Sheiham A. Numbers of natural teeth, diet, and nutritional status in US adults. J DentRes 2007; 86: 1171-1175.

26) Wakai K, Naito M, Naito T, Kojima M, Nakagaki H, Umemura O, et al. Tooth loss and intakes of nutrients and foods: a nationwide survey of Japanese dentists. Community Dent OralEpidemiol 2010; 38: 43-49.

27) Ritchie CS, Joshipura K, Silliman RA, Miller B, Douglas CW. Oral health problems and significant weight loss among community-dwelling older adults. J Gerontol A Biol Sci Med Sci 2000; 55: M366-371.

28) Osterberg T, Dey DK, Sundh V, Carlsson GE, Jansson JO, Mellstrom D. Edentulism associated with obesity: a study of four national surveys of 16416 Swedes aged 55-84 years. Acta Odontol Scand 2010; 68: 360-367.

29) Nakamura K, Nagata C, Oba S, Takatsuka N, Shimizu $\mathrm{H}$. Fruit and vegetable intake and mortality from cardiovascular disease are inversely associated in Japanese women but not in men. J Nutr 2008; 138: 1129 1134.

30) Joshipura KJ, Hung HC, Li TY, Hu FB, Rimm EB, Stampfer MJ, et al. Intakes of fruits, vegetables and carbohydrate and the risk of CVD. Public Health Nutr 2009; 12: 115-121.

31) Soerjomataram I, Oomen D, Lemmens V, Oenema A, Benetou V, Trichopoulou A, et al. Increased consumption of fruit and vegetables and future cancer incidence in selected European countries. Eur J Cancer 2010; 46: 2563-2580.

32) Carter P, Gray LJ, Troughton J, Khunti K, Davies MJ. Fruit and vegetable intake and incidence of type 2 diabetes mellitus: systematic review and metaanalysis. Bmj 2010;341:c4229.

33) Crowe FL, Roddam AW, Key TJ, Appleby PN, Overvad K, Jakobsen MU, et al. Fruit and vegetable intake and mortality from ischaemic heart disease: results from the European Prospective Investigation into Cancer and Nutrition (EPIC)-Heart study. Eur Heart J 201 1; 32: 1235-1243.

34) Polzer I, Schwahn C, Volzke H, Mundt T, Biffar R. The association of tooth loss with all-cause and circulatory mortality. Is there a benefit of replaced teeth? A systematic review and meta-analysis. Clin Oral Investig 2012; 16:333-351.

35) Fukai K, Takiguchi T, Ando Y, Aoyama H, Miyakawa Y, Ito G, et al. Mortality rates of community-residing adults with and without dentures. Geriatr Gerontol Int 2008; 8: 152-159.

36) Yoshida M, Morikawa H, Yoshikawa M, Tsuga K, Akagawa Y. Eight-year mortality associated with dental occlusion and denture use in communitydwelling elderly persons. Gerodontology 2005; 22: 234-237.

37) Shimazaki Y, Soh I, Saito T, Yamashita Y, Koga T, Miyazaki $\mathrm{H}$, et al. Influence of dentition status on physical disability, mental impairment, and mortality in institutionalized elderly people. J Dent Res 2001; 80:340-345.

38) Schwahn C, Polzer I, Haring R, Dorr M, Wallaschofski $\mathrm{H}$, Kocher T, et al. Missing, unreplaced teeth and risk of all-cause and cardiovascular mortality. Int J Cardiol2012; doi:10.1016/j.ijcard.2012.04.061.

39) Moynihan PJ, Butler TJ, Thomason JM, Jepson NJ. Nutrient intake in partially dentate patients: the effect of prosthetic rehabilitation. J Dent 2000; 28: 557- 
563.

40) Wostmann B, Michel K, Brinkert B, MelchheierWeskott A, Rehmann P, Balkenhol M. Influence of denture improvement on the nutritional status and quality of life of geriatric patients. J Dent 2008; 36: 816-821.

41) Awad MA, Morais JA, Wollin S, Khalil A, Gray-Donald K, Feine JS. Implant overdentures and nutrition: a randomized controlled trial. J Dent Res 2012; 91: 3946.
著者連絡先 : 池邊 一典

干565-0871 大阪府吹田市山田丘 1-8

Tel: 06-6879-2956

Fax: 06-6879-2957

E-mail:ikebe@dent.osaka-u.ac.jp 


\section{How Do Occlusion and Masticatory Function Contribute to General Health and Longevity? \\ -A Review of Literature-}

Kazunori Ikebe, DDS, PhD

Department of Prosthodontics, Gerodontology and Oral Rehabilitation, Osaka University Graduate School of Dentistry

Ann Jpn Prosthodont Soc 4: 388-396, 2012

\section{ABSTRACT}

Papers related to the question of "how occlusion and masticatory function contribute to general health and longevity" were reviewed. Longitudinal cohort studies on humans were examined. There are many confirmed factors associated with incidence of fatal diseases or mortality, such as smoking, dietary habits, and socioeconomic factors. Therefore I selected researches of the association between oral health and general health or life expectancy adjusted for these confounding factors by a multivariate analysis.

From the literature survey, it is concluded that (1) the number of teeth is associated with longevity; (2) the pathway for the association should be infection and inflammation resulting from periodontal disease and nutritional change by the decline of oral functions; (3) tooth loss decreases intakes of vegetables, which are important for the prevention of cardiovascular diseases; (4) among fully-edentulous patients and partiallyedentulous patients with a few teeth, a disuse removable dentures may cause short life expectancy; (5) at the present time, there is little evidence of the association of quality of prostheses or oral function with general health and longevity.

\section{Key words}

longitudinal study, longevity, cardiovascular disease, number of teeth, mastication, nutrition, prosthesis, confounding factor 